\title{
Emerging Tickborne Viral Infections: What Wilderness Medicine Providers Need to Know
}

\author{
James H. Diaz, MD, MPH\&TM, DrPH, FACOEM, FASTMH \\ Louisiana State University Health Sciences Center, New Orleans, Louisiana
}

\begin{abstract}
Ticks are versatile vectors of infectious diseases and transmit a broad range of pathogens, including bacteria, viruses, and parasites. Ticks harbor pathogens without infection and share pathogens with other ticks while feeding together on a host. The primary objective of this review is to identify tickborne viral pathogens in the United States, focusing on emerging pathogens. Additional objectives include describing the epidemiology of tick-transmitted viruses, identifying the most common tick vectors of viral pathogens in the United States, identifying the most common tick-transmitted viruses worldwide, and recommending effective strategies for the prevention and treatment of tickborne viral infections. Flaviviruses transmitted by ixodid ticks cause most tickborne viral infections that present clinically as either encephalitis or hemorrhagic fever. Recently, several new tickborne viruses have emerged in the United States, including Bourbon virus, Heartland virus, Powassan virus, and the severe fever with thrombocytopenia syndrome virus transmitted by a tick recently introduced from China, the Asian long-horned tick (Haemaphysalis longicornis). In most cases, there are no specific drug therapies for tickborne viral infections, and treatment is supportive. Vaccination, personal protection, landscape management, and wildlife management are all effective strategies for the primary prevention and control of tickborne viral infectious diseases.
\end{abstract}

Keywords: ticks, viruses, encephalitis, hemorrhagic fever

\section{Introduction}

Ticks are versatile arthropod vectors of zoonotic infectious diseases. They can harbor pathogens without being affected themselves. They transmit more pathogens than other arthropods, including bacteria, viruses, and parasites. Ticks and tickborne infectious diseases are becoming increasingly problematic in the United States, with new invasive species and new pathogens described frequently over expanding geographic ranges. The objectives of this review are to identify known tickborne viral pathogens worldwide and to focus on emerging tickborne viruses in the United States. Additional objectives are to describe the evolving epidemiology of tick-transmitted viral infections; to identify the most common tick vectors of viral

Corresponding author: James H. Diaz, MD, DrPH, Louisiana State University Health Sciences Center, Schools of Public Health and Medicine, 2020 Gravier Street, Third Floor, New Orleans, Louisiana 70112; e-mail: jdiaz@1suhsc.edu.

Submitted for publication March 2020.

Accepted for publication June 2020. pathogens, their zoonotic reservoirs, and ranges of distribution in the United States and worldwide; and to recommend effective strategies for the prevention and treatment of tickborne viral diseases.

\section{Literature search methodology}

Keywords were used to query several Internet search engines, including PubMed, Medline, Ovid, Google, Google Scholar, and the Cochrane Database of Systematic Reviews. The keywords queried included ticks, viruses, encephalitis, and hemorrhagic fever. The study period was 1970 to 2018. The articles reviewed included molecular seroprevalence studies, disease surveillance studies, review articles, entomologic studies, case reports and series, and disease outbreak investigations (Table 1). Articles reviewed but excluded as references included tickborne bacterial and parasitic disease studies, letters to the editor, opinion-editorial articles, and abstracts of posters and presentations at conferences and scientific meetings. The selected methodology met all recommended criteria for narrative reviews, including use of several keywords, use of 2 
Table 1. Scientific articles reviewed, referenced, and stratified by subtypes

\begin{tabular}{|c|c|c|c|c|c|c|c|}
\hline \multirow[t]{2}{*}{ Methods } & \multicolumn{6}{|c|}{ Stratification by subtypes } & \multirow[t]{2}{*}{ Totals } \\
\hline & $\begin{array}{l}\text { Molecular } \\
\text { seroprevalence } \\
\text { studies }\end{array}$ & $\begin{array}{l}\text { Disease } \\
\text { surveillance } \\
\text { studies }\end{array}$ & $\begin{array}{l}\text { Review } \\
\text { articles }\end{array}$ & $\begin{array}{l}\text { Entomological } \\
\text { articles }\end{array}$ & $\begin{array}{l}\text { Case } \\
\text { reports } \\
\text { and series }\end{array}$ & $\begin{array}{l}\text { Outbreak } \\
\text { investigations }\end{array}$ & \\
\hline $\begin{array}{l}\text { Reviewed and } \\
\text { stratified }\end{array}$ & 5 & 10 & 19 & 19 & 12 & 10 & 74 \\
\hline Referenced & 2 & 1 & 7 & 9 & 5 & 3 & 27 \\
\hline
\end{tabular}

or more Internet search engines, a defined study period, and article inclusion and exclusion criteria. ${ }^{1}$

\section{Tick biology and behavior}

There are 4 stages in the life cycle of a tick: egg, 6-legged larva, nymph, and adult. Adult ticks have disk-shaped bodies with 8 legs. ${ }^{2}$ Female ticks of all families are significantly larger than males. Ticks are classified into 3 families: (1) Ixodidae, or hard ticks; (2) Argasidae, or soft ticks; and (3) Nuttalliellidae, a lesser known family with characteristics of both hard and soft ticks. ${ }^{2}$ Ixodid ticks have a hard dorsal plate or scutum, which is absent in the soft-bodied, leathery argasid ticks. With the exception of their sizes, female and male argasid ticks look alike. ${ }^{2}$ Ixodid ticks display more sex differences than argasid ticks, including scutum colors, markings, and shapes. ${ }^{2}$ Ixodid ticks have mouthparts that are attached anteriorly and visible dorsally. Argasid ticks have subterminally attached mouthparts that are not visible dorsally. Ixodid ticks live in open environments, such as woodlands, grasslands, meadows, and scrub brush areas. ${ }^{2}$ Argasid ticks live in sheltered environments, including animal nests, caves, crevices, woodpiles, and uninhabited rural cabins. ${ }^{2}$

Some ixodid ticks are easier to identify than others by their dorsal scutum colors, markings, shapes, and visible mouthparts. ${ }^{2}$ In addition to morphologic characteristics, experts rely on molecular methods to precisely identify ticks and their pathogens. ${ }^{2}$ Ticks can transmit pathogens vertically through transovarian transmission. ${ }^{2}$ In addition, most ticks harbor pathogens across their generations through transstadial transmission. ${ }^{2}$ Nymphal ticks and adult ticks of either sex are capable of transmitting pathogens to humans and other mammals. ${ }^{2}$ Some viral diseases, such as Powassan virus disease, are often transmitted by nymphal ticks, which are harder to spot and remove than adult ticks. ${ }^{2}$ Some flaviviruses are transmitted exclusively by mosquitoes, including dengue, yellow fever, Japanese encephalitis, and Zika virus. The tickborne flaviviruses are also vector specific and only transmitted by ticks. ${ }^{2}$

Ticks sense warm-blooded hosts by vibration and exhaled carbon dioxide. ${ }^{2}$ All ticks feed by cutting a small hole in the host's epidermis using chelicerae and inserting hypostomes into the wound, with blood flow maintained by salivary anticoagulants. ${ }^{2}$ Soft ticks blood-feed rapidly for $1 \mathrm{~h}$ and then drop off, whereas hard ticks blood-feed for 6 to $12 \mathrm{~d}$ and then drop off for mating or egg laying. ${ }^{2}$ The sooner hard ticks are spotted and removed, preferably within 12 to $24 \mathrm{~h}$, the less likely they are to transmit pathogens. ${ }^{2,3}$ Soft ticks and nymphal ticks will bloodfeed immediately and can transmit pathogens rapidly without a lag phase. ${ }^{2,3}$ Although ticks from all 3 families may serve as vectors, the ixodid ticks are responsible for most tickborne diseases worldwide and can transmit multiple pathogens during blood-feeding. ${ }^{2}$

\section{Molecular biology and taxonomy of tickborne viruses}

There are 4 families of tickborne viruses, all of which are enveloped RNA viruses. The families include the flaviviruses (family Flaviviridae), bunyaviruses (family Bunyaviridae), orthomyxoviruses (family Orthomyxoviridae), and coltiviruses (family Reoviridae). The flaviviruses are characterized by specific vectors (tick or mosquito transmitted), with most tickborne viral infections transmitted by ixodid ticks. ${ }^{2}$ The bunyaviruses are described by their animal reservoirs in rodents and include the hantaviruses. The orthomyxoviruses replicate in the host cell nucleus like retroviruses and include the thogotoviruses (Heartland virus). The coltiviruses are characterized by their doublestranded RNA structure and include the Colorado tick fever virus that lends its name to the family ("colti"'-viruses).

\section{Descriptive epidemiology of tickborne viral infections}

Tickborne viral infections present clinically as either encephalitis or hemorrhagic fever and seasonally in the spring through fall (Table 2).

\section{TICKBORNE VIRAL ENCEPHALITIDES}

Most cases of tickborne encephalitis are asymptomatic. In symptomatic cases, illnesses begin with flulike stages with fever, headache, and myalgia, followed by afebrile periods 
Table 2. Clinical features of tickborne encephalitides vs hemorrhagic fevers

\begin{tabular}{|c|c|c|}
\hline Clinical features & Tickborne encephalitides & Tickborne hemorrhagic fevers \\
\hline \multirow{6}{*}{$\begin{array}{l}\text { Epidemiology and presenting } \\
\text { clinical manifestations }\end{array}$} & Seasonal occurrence spring-fall & Seasonal occurrence spring-fall \\
\hline & $1 \mathrm{wk}$ incubation period & $5-14 \mathrm{~d}$ incubation period \\
\hline & Most cases asymptomatic & Most cases symptomatic \\
\hline & Relapsing febrile, flu-like prodrome & Initial febrile flu-like prodrome followed by \\
\hline & followed by meningeal signs and & hepatomegaly, hepatic insufficiency, and \\
\hline & $\begin{array}{l}\text { cognitive dystunction, } \\
\text { especially in infants and elderly }\end{array}$ & $\begin{array}{l}\text { coagulopathy } \\
\text { No age-related specificity }\end{array}$ \\
\hline Differential diagnosis & $\begin{array}{l}\text { Seasonal spring-fall mosquito-borne } \\
\text { encephalitides: La Crosse encephalitis, } \\
\text { St. Louis encephalitis, West Nile virus } \\
\text { encephalitis, and neuroinvasive disease }\end{array}$ & $\begin{array}{l}\text { Tickborne bacterial diseases: Ehrlichiosis, } \\
\text { Rocky Mountain spotted fever, and other } \\
\text { rickettsial infections }\end{array}$ \\
\hline \multirow[t]{2}{*}{ Laboratory diagnosis } & Cerebrospinal fluid serology & Acute and convalescent serology \\
\hline & $\begin{array}{l}\text { Nucleic acid detection by polymerase } \\
\text { chain reaction }\end{array}$ & $\begin{array}{l}\text { Nucleic acid detection by polymerase chain } \\
\text { reaction }\end{array}$ \\
\hline Complications & $\begin{array}{l}\text { Cranial nerve palsies, seizures, } \\
\text { cerebrovascular accident }\end{array}$ & $\begin{array}{l}\text { Intrapulmonary and intracerebral hemorrhage, } \\
\text { disseminated intravascular coagulation }\end{array}$ \\
\hline Outcomes & $\begin{array}{l}\text { Persistent neurologic dysfunction } \\
\text { possible, such as ataxia and tremors }\end{array}$ & Nosocomial and aerosol transmission common \\
\hline Case fatality rates & Up to $10 \%$ & $5-80 \%$ with coagulopathy \\
\hline \multirow[t]{2}{*}{ Treatment } & Nonspecific and supportive & Mostly nonspecific and supportive \\
\hline & & $\begin{array}{l}\text { Ribavirin for Crimean-Congo hemorrhagic } \\
\text { fever }\end{array}$ \\
\hline \multirow[t]{3}{*}{ Prevention } & Rapid tick removal & Rapid tick removal \\
\hline & $\begin{array}{l}\text { Personal protection with clothing and } \\
\text { topical repellants }\end{array}$ & $\begin{array}{l}\text { Personal protection with clothing and topical } \\
\text { repellants }\end{array}$ \\
\hline & Vaccines available in Europe and Asia & Vaccines available in Eastern Europe \\
\hline
\end{tabular}

and recovery with immunity. A second stage may occur in more severe cases, especially in the elderly, that presents with a meningoencephalitis pattern. Clinical findings in this stage may include altered mental status, cognitive dysfunction, meningeal signs, cranial nerve palsies, ataxia, rigidity, tremors, and seizures, with increased case fatality rates from seizures and strokes. ${ }^{3}$ Altered mental status and seizure disorders may persist, especially after Powassan virus encephalitis, but do not represent chronic or prolonged infections. ${ }^{3}$

From a global distribution perspective, the tickborne encephalitis viruses (TBEVs) are divided into the Old World (eastern hemisphere) strains and New World (western hemisphere) strains, with the Old World strains having higher case fatality rates $(20-40 \%)$ and permanent neurologic morbidity rates $(28-30 \%)$ than the New World strains (case fatality rate, $10-15 \%$; neurological morbidity rate $<10 \%){ }^{3}$

\section{Old World TBEVs}

The Old World TBEVs are stratified geographically into 3 subtypes: 1) European or Central European, 2) Siberian or Russian spring-summer, and 3) Far Eastern (Table 3). ${ }^{3}$
The preferred wild animal reservoirs for TBEVs include rodents, insectivores, medium-sized mammals, deer and other ungulates, birds, and, less often, domestic animals (Table 3). ${ }^{3}$ High viral inocula render early removal of the feeding tick relatively ineffective in preventing encephalitis virus transmission. ${ }^{3}$ Among the Old World TBEVs, the clinical course and outcome vary by age and subtype, with higher case fatality rates in the elderly and in Far Eastern and Siberian TBEVs than in European TBEV.

\section{New World TBEVs}

The New World TBEVs include Powassan virus and deer tick virus (Table 3 ). The Powassan encephalitis virus typifies a New World TBEV, with a highly confined regional distribution in the New England states (Connecticut, Massachusetts, and New York) and Eastern Canada. ${ }^{4}$ Although historically confined to these endemic regions, the virus moved westward in ixodid ticks after 2008 and caused case clusters in Minnesota and Wisconsin, with high case fatality rates in the elderly. ${ }^{5}$

Powassan virus has several preferred ixodid tick vectors and an extensive wild animal reservoir in rodents and small mammals, especially woodchucks and skunks. ${ }^{4-6}$ 
Table 3. Tickborne encephalitis viruses

\begin{tabular}{|c|c|c|c|}
\hline Virus species (family) & Geographic distribution & Tick vectors & Animal reservoirs \\
\hline $\begin{array}{l}\text { Central European tickborne } \\
\text { encephalitis (Flaviviridae) }\end{array}$ & $\begin{array}{l}\text { Europe, except Iberian } \\
\text { Peninsula }\end{array}$ & $\begin{array}{l}\text { Ixodid ticks, especially } \\
\text { Dermacentor } \\
\text { marginatus, } \\
\text { Ixodes persulcatus, } \\
\text { and I ricinus }\end{array}$ & $\begin{array}{l}\text { Mammals. Particular reservoirs: } \\
\text { rodents, including hedgehogs, wood } \\
\text { mice, and voles; deer and other } \\
\text { ungulates; birds; domestic livestock, } \\
\text { especially goats }\end{array}$ \\
\hline Deer tick virus (Flaviviridae) & $\begin{array}{l}\text { New England states } \\
\text { (Connecticut, Massachusetts, } \\
\text { New York) }\end{array}$ & Ixodes scapularis & Deer \\
\hline $\begin{array}{l}\text { Far Eastern TBE } \\
\text { (Flaviviridae) }\end{array}$ & $\begin{array}{l}\text { Eastern Russia, China to } \\
\text { Far Eastern Japan }\end{array}$ & I persulcatus & $\begin{array}{l}\text { Mammals. Particular reservoirs: } \\
\text { rodents, including hedgehogs, wood } \\
\text { mice, voles; birds; deer and other } \\
\text { ungulates; domestic livestock, } \\
\text { especially goats }\end{array}$ \\
\hline Langat (Flaviviridae) & Malaysia & Ixodid ticks & Mammals-monkeys, rodents \\
\hline Louping Ill (Flaviviridae) & United States, Scotland & Ixodid ticks & Sheep \\
\hline $\begin{array}{l}\text { Powassan encephalitis } \\
\text { (Flaviviridae) }\end{array}$ & $\begin{array}{l}\text { Canada, US Northeast, } \\
\text { Far Eastern Russia }\end{array}$ & $\begin{array}{l}\text { Ixodes spp, particularly } \\
\text { I scapularis } \\
\text { I cookei, Dermacentor } \\
\text { andersoni }\end{array}$ & $\begin{array}{l}\text { Mammals—rodents, skunks, and } \\
\text { other medium-sized mammals, } \\
\text { especially woodchucks }\end{array}$ \\
\hline $\begin{array}{l}\text { Siberian (Russian) } \\
\text { spring-summer encephalitis } \\
\text { (Flaviviridae) }\end{array}$ & Russia & $\begin{array}{l}\text { Ixodes spp, I } \\
\text { persulcatus, I ricinus }\end{array}$ & $\begin{array}{l}\text { Mammals. Particular reservoirs: } \\
\text { rodents including hedgehogs, wood } \\
\text { mice, voles; birds; deer and other } \\
\text { ungulates; domestic livestock, } \\
\text { especially goats }\end{array}$ \\
\hline $\begin{array}{l}\text { Turkish sheep encephalitis } \\
\text { (Flaviviridae) }\end{array}$ & Turkey & Ixodid ticks & Sheep \\
\hline Bhanja virus (Bunyaviridae) & $\begin{array}{l}\text { Eastern Europe, Russia, } \\
\text { Central and West Africa }\end{array}$ & $\begin{array}{l}\text { Dermacentor spp } \\
\text { Haemaphysalis } \\
\text { intermedia }\end{array}$ & Cattle, sheep, goats, hedgehogs \\
\hline $\begin{array}{l}\text { Crimean-Congo hemorrhagic } \\
\text { fever (Bunyaviridae) }\end{array}$ & $\begin{array}{l}\text { Asia, Eastern Europe, Africa, } \\
\text { Middle East }\end{array}$ & $\begin{array}{l}\text { Hyalomma marginatum, } \\
\text { Hyalomma anatolicum }\end{array}$ & $\begin{array}{l}\text { Mammals-many domestic animals } \\
\text { (buffalo, camels, cattle, goats, } \\
\text { sheep), rabbits, rodents (hedgehogs), } \\
\text { birds }\end{array}$ \\
\hline
\end{tabular}

Powassan virus is transmitted to humans by blood-feeding ixodid ticks in $15 \mathrm{~min}$ or less, often by nymphal ticks. Cases occur seasonally from May to December and peak during June to September, when ticks are most active. ${ }^{4-6}$ Powassan virus infections mimic the mosquito-borne viral encephalitides, such as La Crosse and St. Louis encephalitis and West Nile virus neuroinvasive disease, in clinical presentation. $^{4-6}$

Patients with Powassan encephalitis present with somnolence, headache, confusion, high fever, weakness, ataxia, and cerebrospinal fluid lymphocytosis. ${ }^{4-6}$ After transient improvement, neurologic deterioration, demyelination on magnetic resonance imaging, and slow neurologic recovery may occur. ${ }^{4-6}$ The case fatality rate can be as high as $10 \%{ }^{4-6}$ Permanent neurologic deficits occur frequently after infection and may include memory loss, weakness, movement disorder, ophthalmoplegia, and lower extremity paraparesis. $^{4,5}$
In Powassan and deer tick virus encephalitis, laboratory diagnosis relies on detection of virus-specific neutralizing IgM antibodies in cerebrospinal fluid or nucleic acid detection by polymerase chain reaction, only available at certain reference laboratories. ${ }^{4-6}$

Because there is no vaccine or specific therapy for Powassan encephalitis, the best protection is prevention of tick bites. The short tick attachment time required for transmission of Powassan virus increases the importance of personal protective measures, such as repellents and proper clothing. ${ }^{4-6}$

The deer tick virus is phylogenetically related to Powassan virus, is transmitted by ixodid ticks, and also has a confined regional distribution in the same endemic regions as Powassan virus in New England and Canada. ${ }^{7}$ It also causes a meningoencephalitis syndrome with high case fatality rates and permanent neurologic sequelae in survivors. ${ }^{7}$ Powassan and deer tick meningoencephalitis 
Table 4. Tickborne hemorrhagic fever viruses

\begin{tabular}{|c|c|c|c|}
\hline Virus species (family) & Geographic distribution & Tick vectors & Animal reservoirs \\
\hline $\begin{array}{l}\text { Alkhurma hemorrhagic } \\
\text { fever (Flaviviridae) }\end{array}$ & Saudi Arabia & Ornithodoros savignyi & Camels, sheep \\
\hline $\begin{array}{l}\text { Omsk hemorrhagic fever } \\
\text { (Flaviviridae) }\end{array}$ & Western Siberia & $\begin{array}{l}\text { Dermacentor reticulatus, } \\
\text { Ixodes apronophorus }\end{array}$ & $\begin{array}{l}\text { Mammals - rodents, especially } \\
\text { muskrats, water voles }\end{array}$ \\
\hline $\begin{array}{l}\text { Kyasanur Forest disease } \\
\text { (Flaviviridae) }\end{array}$ & Western India & Haemaphysalis spinigera & $\begin{array}{l}\text { Mammals-especially monkeys, } \\
\text { domestic livestock (cattle, goats, } \\
\text { sheep), rodents, insectivores }\end{array}$ \\
\hline $\begin{array}{l}\text { Heartland virus } \\
\text { (Bunyaviridae) }\end{array}$ & $\begin{array}{l}\text { Missouri, Kansas, } \\
\text { Tennessee }\end{array}$ & Amblyomma americanum & $\begin{array}{l}\text { Mammals-rodents, skunks, } \\
\text { other medium-sized mammals }\end{array}$ \\
\hline $\begin{array}{l}\text { Crimean-Congo } \\
\text { hemorrhagic fever } \\
\text { (Bunyaviridae) }\end{array}$ & $\begin{array}{l}\text { Asia, Eastern Europe, } \\
\text { Africa, Middle East }\end{array}$ & $\begin{array}{l}\text { Hyalomma marginatum, } \\
\text { Hyalomma anatolicum }\end{array}$ & $\begin{array}{l}\text { Mammals - many domestic animals } \\
\text { (buffalo, camels, cattle, goats, sheep), } \\
\text { rabbits, rodents (hedgehogs), birds }\end{array}$ \\
\hline $\begin{array}{l}\text { Severe fever with } \\
\text { thrombocytopenia } \\
\text { virus (Bunyaviridae) }\end{array}$ & $\begin{array}{l}\text { China (mostly), } \\
\text { Japan, Korea }\end{array}$ & $\begin{array}{l}\text { Haemaphysalis spp, } \\
\text { especially } H \text { longicornis } \\
>\text { H concinna }\end{array}$ & $\begin{array}{l}\text { Primarily domestic animals, } \\
\text { especially goats }\end{array}$ \\
\hline $\begin{array}{l}\text { Bourbon virus } \\
\text { (Orthomyxoviridae) }\end{array}$ & $\begin{array}{l}\text { Missouri, Kansas, } \\
\text { Oklahoma }\end{array}$ & Unknown & Unknown \\
\hline
\end{tabular}

are clinically indistinguishable and can only be differentiated by molecular methods at reference laboratories. ${ }^{7}$

\section{Tickborne hemorrhagic fever viruses}

The tickborne hemorrhagic fever (TBHF) viruses are distributed worldwide and share many clinical features. The coagulopathy of all TBHFs may manifest as any combination of petechiae, purpura, subconjunctival and pharyngeal hemorrhage, thrombocytopenia, cerebral hemorrhage, intrapulmonary hemorrhage, and disseminated intravascular coagulation. ${ }^{8-11}$ Case fatality rates range from 10 to over 50\%, with most deaths occurring from intracerebral or intrapulmonary hemorrhage within 5 to $14 \mathrm{~d}$ of symptom onset during hemorrhagic stages. ${ }^{8-11}$

The flaviviruses and bunyaviruses transmitted by ixodid ticks cause most of the TBHFs (Table 4). These viruses are widely distributed throughout Eastern Europe, Africa, and Asia. Emerging viral causes of TBHFs in the United States include Heartland virus, Bourbon virus, and the severe fever with thrombocytopenia syndrome (SFTS) virus. The Asian tick vector of SFTS virus, Haemaphysalis longicornis, is now endemic in the eastern United States, and its regional interstate distribution range has increased (Figures 1 and 2). ${ }^{12}$ Several mechanisms other than tick bites can transmit the TBHF viruses, including inhalation of aerosols created by crushing infected ticks, direct contact with blood or tissues from infected animals or humans, and nosocomial spread among medical personnel. ${ }^{8-10}$

\section{HEARTLAND VIRUS}

The Heartland virus, a novel Phlebovirus (family Bunyaviridae) transmitted by the Lone Star tick (Amblyomma americanum), was first described in 2009 in 2 elderly Missouri farmers with histories of tick bites (Figure 3). ${ }^{13,14}$ Both patients presented with fever, fatigue, headache, confusion, myalgia, leukopenia, and thrombocytopenia. ${ }^{13}$ Tickborne infections were suspected, and both patients were treated with antibiotics for ehrlichiosis with good outcomes. ${ }^{13}$ In addition to the 2 index cases, 6 more cases of Heartland virus disease were reported during 2012 to 2013, 5 from Missouri and 1 from Tennessee. In 2013, the first fatal case of Heartland virus disease occurred in an 80-y-old man in Tennessee who presented with similar clinical and laboratory findings and multiple comorbidities but could not recall a tick bite. ${ }^{15}$ Other than supportive care, there are no specific drug treatments for Heartland virus disease. $^{13,15}$

\section{BOURBON VIRUS}

In June 2014, a previously healthy man over 50 y of age in eastern Kansas who presented with a history of tick bite, fever, and fatigue received oral doxycycline for a presumed tickborne rickettsial infection. ${ }^{16} \mathrm{He}$ later died from a critical illness characterized by high fever, thrombocytopenia, leukopenia, and multiorgan failure. ${ }^{16}$ Serologic tests ruled out Heartland virus disease, initially suspected given the earlier cases in nearby Missouri. ${ }^{13,16}$ Subsequently, a series of serologic, microbiologic, and molecular tests demonstrated a novel thogogotovirus (family Orthomyxoviridae) phylogenetically distinct from Heartland virus. ${ }^{16}$ The new virus was named Bourbon virus after the patient's county of residence. ${ }^{16}$ Unlike Bourbon virus fatalities, Heartland virus fatalities have been confined to the elderly. ${ }^{13-16}$ 


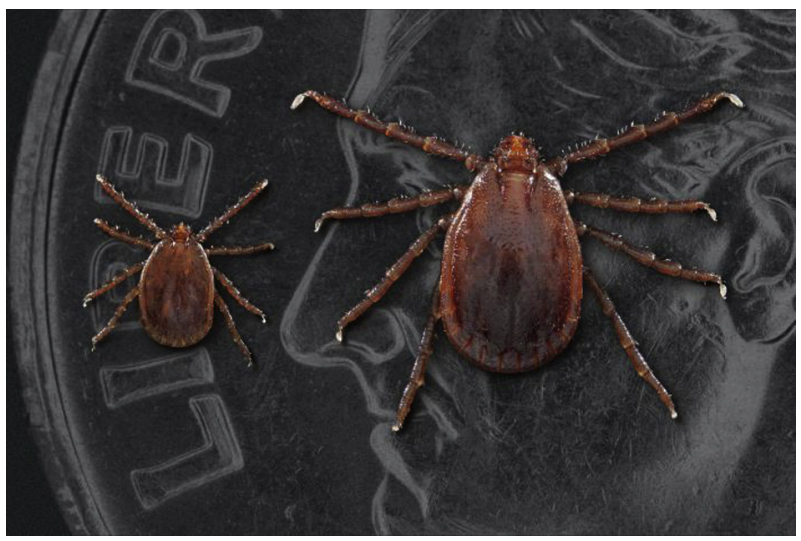

Figure 1. This photograph depicts 2 Haemaphysalis longicornis ticks, commonly known as the longhorned tick. The smaller of the 2 ticks, on the left, is a nymph. The larger tick is an adult female. Males are rare. This tick can reproduce asexually. Note that the ticks have been placed atop a US dime to provide a sense of scale. Source: United States Centers for Disease Control and Prevention. (Available at: https://phil.cdc.gov/ Details.aspx?pid=22872. Photo credit: James Gathany, CDC.)

\section{SFTS VIRUS}

Another novel tick-transmitted Phlebovirus (family Bunyaviridae), the SFTS virus, was first described in 2009 in China and has now been detected in Haemaphysalis spp ticks in Japan and Korea. ${ }^{9,17,18}$ SFTS virus is transmitted by at least 2 species of Haemaphysalis spp ticks in Asia, $H$ longicornis and $H$ concinna (Figure 1). ${ }^{17,18}$

Domestic animals, especially goats, serve as the zoonotic reservoirs for the SFTS virus in China. ${ }^{17,18}$ Central and eastern China report the greatest number of cases,

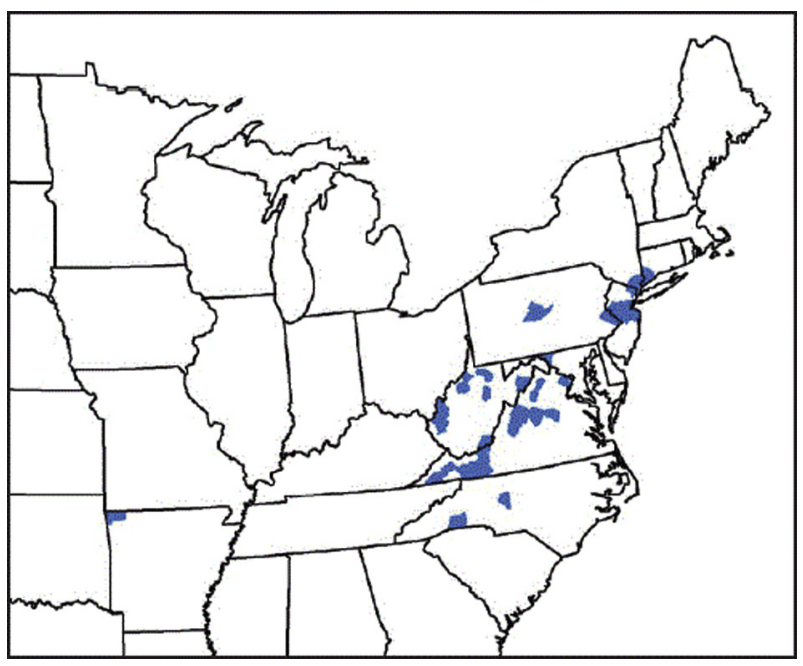

Figure 2. The current distribution range of Haemaphysalis longicornis, the Asian longhorned tick, in the eastern United States and northwestern Arkansas. (Source: United States Centers for Disease Control and Prevention. Available at: https://www.cdc.gov/mmwr/volumes/67/wr/ mm6747a3.htm.) with over 2500 reported since $2010 .{ }^{17-19}$ The disease presents with a sudden onset of high fever, abdominal pain, nausea, vomiting, leukocytopenia, thrombocytopenia, and hemorrhage. ${ }^{17,19}$ There are no specific drug treatments for SFTS virus disease. ${ }^{17,19}$ The median case fatality rate is 7\%. ${ }^{17,19}$

$H$ longicornis, the Asian longhorned tick, is native to eastern China, Japan, the Russian Far East, and Korea (Figure 1). ${ }^{20}$ It is an introduced, and now established, exotic species in Australia, New Zealand, several island nations in the western Pacific, and the United States. ${ }^{12,21,22}$

The initial US detection of $H$ longicornis outside of imported animal quarantine was on a sheep in New Jersey in August 2017. ${ }^{12}$ By the spring of 2018, the tick was again detected at the same site in New Jersey, and later in other counties in New Jersey, 7 other states in the eastern United States, and northwestern Arkansas (Figure 2). ${ }^{22}$ The animal hosts included 6 species of domestic animals, 6 species of wildlife, and humans. ${ }^{22}$ At present, there is no evidence that $H$ longicornis has transmitted any pathogens to humans, domestic animals, or wildlife in the United States. ${ }^{22} H$ longicornis is, however, capable of transmitting several pathogens, including bacteria (Rickettsia, Borrelia, Ehrlichia, Anaplasma, and Theileria spp.), viruses (Bourbon, Heartland, and SFTS viruses), and, probably, parasites (Babesia spp). ${ }^{22}$

\section{CRIMEAN-CONGO HEMORRHAGIC FEVER VIRUS}

Crimean-Congo hemorrhagic fever is among the most commonly encountered tickborne viral infections in Eastern Europe, Asia, and sub-Saharan Africa. ${ }^{8,23}$ CrimeanCongo hemorrhagic fever is characterized by a suddenonset high fever, headache, back and joint pain, nausea, and vomiting. ${ }^{8,10,11}$ As the disease progresses, coagulopathy ensues with petechiae, bruising, nosebleeds, and bleeding from injection sites. Jaundice is often present. Reported case fatality rates from outbreaks or case series range from 5 to $80 \%{ }^{8,10,11}$

Diagnostic laboratory techniques include serologic tests, immunohistochemical staining to microscopically identify antigen in tissues, and identification of viral RNA in blood or tissues by polymerase chain reaction. ${ }^{8,10,11}$

All patients with confirmed or suspected CrimeanCongo hemorrhagic fever should be isolated. ${ }^{8,10}$ Fatal nosocomial transmission has occurred, most likely by the generation of infectious aerosols during endotracheal intubation, bronchoscopy, and bag-valve-mask ventilation. ${ }^{10}$ Medical personnel managing patients with CrimeanCongo hemorrhagic fever should follow strict universal precautions and wear personal protective equipment including gowns, gloves, eye protection and face shields, and respirator masks. ${ }^{10}$ 


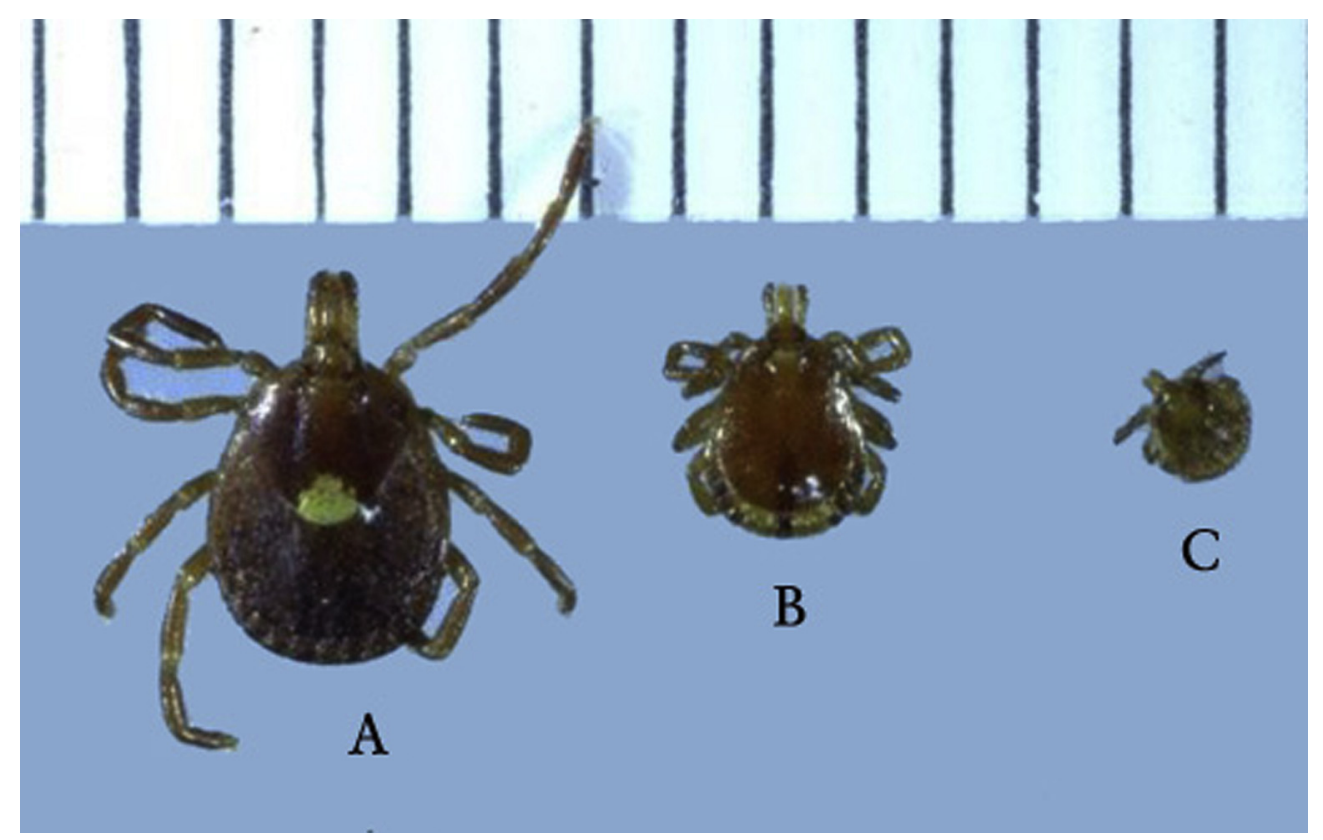

Figure 3. Amblyomma americanum, the North American Lone Star tick, is the vector of the Heartland virus. The scale interval is in millimeters. (A) female, (B) male, (C) nymph, dorsal views. (Source: United States Centers for Disease Control and Prevention, Atlanta, Georgia. Public domain, no copyright permission required. Available at: https://www.cdc.gov/dpdx/ticks/index.html.)

Intravenous ribavirin therapy can inhibit CrimeanCongo hemorrhagic fever virus replication in animal models, but it has not undergone clinical trials in humans with Crimean-Congo hemorrhagic fever. ${ }^{8,10,11}$ Nevertheless, if TBHF is suspected and laboratory confirmation is unavailable, intravenously administered ribavirin is recommended for severe cases. Oral ribavirin is recommended for all highrisk contacts. ${ }^{8,10,11}$

A mouse brain-derived Crimean-Congo hemorrhagic fever vaccine is available in Bulgaria, but not elsewhere. In the absence of a universal vaccine, the best preventive measures for the TBHFs are tick avoidance, rapid burial of dead animals, and personal protective equipment for medical personnel. ${ }^{10,11}$

\section{Tickborne coltiviruses}

Distinct from the other 3 families of single-stranded-RNA tickborne viruses, the coltiviruses (family Reoviridae) are all double-stranded-RNA viruses. ${ }^{24}$ They include 4 subtypes: 1) Colorado tick fever virus, endemic in the United States and Canadian Rocky Mountain regions; 2) the California tick fever virus of rabbits, a serotype of the Colorado tick fever virus that only affects rabbits; 3 ) the Salmon River virus of Idaho; and 4) the European Eyach virus. ${ }^{24}$ The ixodid ticks are the only vectors of the coltiviruses. ${ }^{24}$ Among the coltiviruses, Colorado tick fever virus has the largest host animal reservoir. ${ }^{24}$
Ixodid ticks maintain the coltivirus in nature by bloodfeeding on wild animal hosts with prolonged viremias. ${ }^{24}$ The ticks then transmit coltiviruses transstadially across generations from nymphs to adults, but not congenitally from females to eggs. ${ }^{24}$ Infected nymphs hibernate over winter. Previously infected nymphs and newly infected adults then transmit coltiviruses to human dead-end hosts during spring-summer blood-feeding. ${ }^{24}$ Congenital and blood transfusion-transmitted cases of Colorado tick fever virus have occurred. ${ }^{24}$

Both Colorado tick fever virus and Salmon River virus can cause relapsing febrile illnesses that mimic mild cases of Rocky Mountain spotted fever without rash. Leukopenia and thrombocytopenia are common laboratory manifestations of coltivirus infections. ${ }^{24}$ Complications are rare but may include meningoencephalitis, orchitis, hemorrhagic fever, pericarditis, and myocarditis. European Eyach virus infections present with more central nervous system manifestations than American tickborne coltivirus infections. ${ }^{24}$

The most common differential diagnoses for tickborne coltivirus infections are other tickborne febrile diseases, most commonly Rocky Mountain spotted fever in North America. ${ }^{24}$ The characteristic rash and leukocytosis of Rocky Mountain spotted fever help to differentiate Rocky Mountain spotted fever from Colorado tick fever and Salmon River virus infections. ${ }^{24}$

Serologic tests to detect anticoltivirus antibodies include complement fixation, seroneutralization assay, 
immunofluorescence assay, enzyme-linked immunosorbent assay, and Western immunoblot. ${ }^{24}$ The most specific confirmatory tests include real-time reverse transcriptase polymerase chain reaction assays to identify Colorado tick fever virus RNA (or the RNA of its cross-reacting serotypes, such as California tick fever virus of rabbits and Salmon River virus) or the isolation of coltiviruses after intracerebral inoculation of infected human blood into suckling mice. ${ }^{24}$ Such sophisticated laboratory tests are only available at certain state and federal laboratories.

Treatment of all tickborne coltivirus infections is supportive. Long-term postinfectious complications are rare in uncomplicated cases in the United States.

\section{Prevention of tickborne viral infectious diseases}

There are several effective strategies to prevent tickborne infectious diseases, including immunization, personal protective measures, landscape management, and wildlife management. Current immunization programs for tickborne viral diseases provide primary prevention of European tickborne encephalitis, Siberian spring-summer encephalitis in Russia and the Middle East, Far Eastern tickborne encephalitis in China and the Far East, and CrimeanCongo hemorrhagic fever in Bulgaria. ${ }^{3}$

Personal protective measures to prevent tick-transmitted diseases include wearing appropriate clothing, using insect repellents, and performing regular tick body checks. Wearing long pants tucked into socks, long-sleeved shirts, and light-colored clothing can help keep ticks off the skin and make them easier to visualize on clothing. Impregnating clothing with permethrin is a highly effective repellent against ticks and other arthropods. The topical application of insect repellents containing 20 to $50 \%$ formulations of $\mathrm{N}, \mathrm{N}$-diethyl-metatoluamide (DEET) directly on the skin is another effective measure. For children and infants $>2$ mo old, DEET concentrations of 10 to $30 \%$ are recommended to avoid adverse neurologic events, which have occurred with prolonged or excessive use. ${ }^{25}$

Most patients with tickborne viral infections do not recall tick bites, especially bites by diminutive nymphs (Figure 3). Nevertheless, tick localization and removal as soon as possible, preferably within 12 to $36 \mathrm{~h}$, are strategies to prevent most tickborne diseases, especially those transmitted by ixodid ticks, such as Lyme disease and rickettsial diseases. ${ }^{26}$ Forceps, tweezers, or special tick removal devices can remove ticks quickly with their feeding mouthparts still attached. ${ }^{26}$ Removing ticks by hand can crush ticks, creating infectious aerosols, or separate ticks from their mouthparts, allowing salivary glands to continue to inject pathogens into the bite wound. ${ }^{26}$ Contraindicated procedures include burning ticks in place with spent matches and painting embedded ticks with adhesives, oils, or nail polishes. ${ }^{26}$

Landscape management strategies to prevent tickborne diseases include widespread regional application of acaricides over tick-preferred ecosystems; removal of vegetation and leaf litter near homes, schools, and recreation sites; and creation of dry barriers of gravel, stone, or wood chips between scrub or forested areas and yards or playgrounds.

Wildlife management strategies to prevent tickborne diseases include development of new veterinary vaccines for tickborne diseases with large domestic animal reservoirs. In addition, topical acaricides can be applied actively to domestic animals such as cattle and pigs and passively to deer at acaricide-baited self-treatment stations located near watering holes and salt licks. Newer control strategies effective in controlling nymphs from blood-feeding on rodents and small mammals include setting out acaricidebaited houses for host animals to occupy or acaricide-baited cotton balls for host animals to adopt as nesting materials in crawl spaces under homes and burrows near playgrounds. ${ }^{27}$

\section{Conclusions}

The flaviviruses transmitted by ixodid ticks cause most tickborne viral infections that present as either encephalitis or hemorrhagic fever. Recently, several new tickborne viruses causing either encephalitis or hemorrhagic fever syndromes have emerged in the United States, including Bourbon virus, Heartland virus, Powassan virus, and the SFTS virus.

The recently introduced tick vector of SFTS, the Asian tick longhorned tick (H longicornis), has been expanding its distribution range in the eastern United States since its first appearance in New Jersey in 2017 (Figure 2). H longicornis is capable of transmitting several pathogens to animals and humans, as it has in China and Korea.

There are no specific drug therapies for tickborne viral infections, other than ribavirin for fulminant CrimeanCongo hemorrhagic fever. Treatment is mainly supportive. Vaccination, personal protection, landscape management, and wildlife management are all effective strategies for the primary prevention and control of tickborne viral infectious diseases.

Financial/Material Support: All financial/material support for JHD was provided by departmental and institutional sources.

Disclosures: None.

\section{References}

1. Murphy CM. Writing an effective review article. J Med Toxicol. 2012;8(2):89-90.

2. Goddard J. Ticks. In: Goddard J, ed. Physician's Guide to Arthropods of Medical Importance. 4th ed. Boca Raton, FL: CRC Press; 2003:327-86. 
3. Lindquist L, Vapalahti O. Tick-borne encephalitis. Lancet. 2008;371(9627):1861-71.

4. Centers for Disease Control and Prevention. Outbreak of Powassan encephalitis-Maine and Vermont, 1999-2001. MMWR Morb Mortal Wkly Rep. 2001;50(35):761-4.

5. Birge J, Sonnesyn S. Powassan virus encephalitis, Minnesota, USA. Emerg Infect Dis. 2012;18(10):1669-71.

6. Tutolo JW, Staples JE, Sosa L, Bennett N. Notes from the field: Powassan virus disease in an infant-Connecticut, 2016. MMWR Morb Mortal Wkly Rep. 2017;66(15):408-9.

7. Tavakoli NP, Wang H, Dupuis M, Hull R, Ebel GD, Gilmore EJ, et al. Fatal case of deer tick virus encephalitis. N Engl J Med. 2009;360(20):2099-107.

8. Watts DM, Flick R, Peters CJ, Shope RE. Bunyaviral fevers: Rift Valley fever and Crimean-Congo hemorrhagic fever. In: Guerrant RL, Walker DH, Weller PF, eds. Tropical Infectious Diseases: Principles, Pathogens, and Practice. 2nd ed. Philadelphia, PA: Churchill Livingstone; 2006:756-61.

9. Bao C, Guo X, Qi X, Hu J, Zhou M, Varma JK, et al. A family cluster of infections by a newly recognized Bunyavirus in eastern China, 2007: further evidence of person-to-person transmission. Clin Infect Dis. 2011;53(12):1208-14.

10. Conger NG, Paolino KM, Osborn EC, Rusnak JM, Gunther S, Pool J, et al. Health care response to CCHF in US soldier and nosocomial transmission to health care providers, Germany 2009. Emerg Infect Dis. 2015;21(1):23-31.

11. Mustafa ML, Ayazi E, Mohareb E, Yingst S, Zayed A, Rossi CA, et al. Crimean-Congo hemorrhagic fever, Afghanistan, 2009. Emerg Infect Dis. 2011;17(10):1940-1.

12. Rainey T, Occi JL, Robbins RG, Egizi A. Discovery of Haemaphysalis longicornis (Ixodida: Ixodidae) parasitizing a sheep in New Jersey, United States. J Med Entomol. 2018;55(3):757-9.

13. Kosoy OI, Lambert AJ, Hawkinson DJ, Pastula DM, Goldsmith CS, Hunt DC, et al. Novel thogotovirus associated with febrile illness and death, United States, 2014. Emerg Infect Dis. 2015;21(5):760-4.

14. Savage HM, Godsey MS, Lambert A, Panella NA, Burkhalter KL, Harmon JR, et al. First detection of Heartland virus (Bunyaviridae: Phlebovirus) from field collected arthropods. Am J Trop Med Hyg. 2013;89(3):445-52.

15. Muehlenbachs A, Fata CR, Lambert AJ, Paddock CD, Velez JO, Blau DM, et al. Heartland virus-associated death in Tennessee. Clin Infect Dis. 2014;59(6):845-50.

16. Lambert AJ, Velez JO, Brault AC, Calvert AE, Bell-Sakyi L, Bosco-Lauth AM, et al. Molecular, serological and in vitro culture-based characterization of the Bourbon virus, a newly described pathogen of the genus Thogotovirus. J Clin Virol. 2015;73:127-32.

17. Silvas JA, Aguilar PV. The emergence of severe fever with thrombocytopenia syndrome virus. Am J Trop Med Hyg. 2017;97(4):992-6.

18. Tian H, Pengbo Y, Chowell C, Li S, Wei J, Tian H, et al. Severe fever with thrombocytopenia syndrome in humans, domestic animals, ticks, and mosquitoes, Shaanxi Province, China. Am J Trop Med Hyg. 2017;96(6): 1346-9.

19. Huang D, Jiang Y, Liu X, Wang B, Shi J, Su Z, et al. A cluster of symptomatic and asymptomatic infections of severe fever with thrombocytopenia syndrome caused by person-toperson transmission. Am J Trop Med Hyg. 2017;97(2): 396-402.

20. Luo LM, Zhao L, Wen HL, Zhang ZT, Liu JW, Fang LZ, et al. Haemaphysalis longicornis ticks as reservoir and vector of severe fever with thrombocytopenia syndrome virus in China. Emerg Infect Dis. 2015;21(10):1770-6.

21. Heath A. Biology, ecology and distribution of the tick, Haemaphysalis longicornis Neumann (Acari: Ixodidae) in New Zealand. N Z Vet J. 2016;64(1):10-20.

22. Beard CB, Occi J, Bonilla DL, Egizi AM, Fonseca DM, Mertins JW, et al. Multistate infestation with the exotic disease-vector tick Haemaphysalis longicornis-United States, August 2017-September 2018. MMWR Morb Mortal Wkly Rep. 2018;67(47):1310-3.

23. Sang R, Lutomiah J, Koka H, Makio A, Chepkorir E, Ochieng C, et al. Crimean-Congo hemorrhagic fever virus in Hyalommid ticks, Northeastern Kenya. Emerg Infect Dis. 2011;17(8):1502-5.

24. Attoui H, Jaafar FM, de Micco P, de Lamballerie X. Coltiviruses and seadornaviruses in North America, Europe, and Asia. Emerg Infect Dis. 2005;11(11):1673-9.

25. Koren G, Matsui D, Bailey B. DEET-based insect repellents: safety implications for children and pregnant and lactating women. CMAJ. 2003;169(3):209-12.

26. United States Center for Disease Control and Prevention. Tick removal. Available at: https://www.cdc.gov/ticks/removing a_tick.html. Accessed March 3, 2020.

27. Schulze TL, Jordan RA, Williams M, Dolan MC. Evaluation of the SELECT tick control system (TCS): a host-targeted bait box, to reduce exposure to Ixodes scapularis (Acari: Ixodidae) in a Lyme disease endemic area of New Jersey. J Med Entomol. 2017;54(4):1019-24. 